\title{
O pintor-parlamentar Pedro Américo em meio às turbulências da Constituinte de 1891
}

\author{
Silvano Alves Bezerra da Silva \\ Universidade Federal do Maranhão
}

\section{Resumo}

Este artigo persegue dois propósitos: o de recompor o trajeto realizado pelo pintor Pedro Américo de Figueiredo e Melo até a Primeira Constituinte republicana brasileira e o de analisar a sua participação nas discussões que deram as bases legais para reger o País após o fim do regime monárquico. Ele articula aspectos de sua vida pessoal e artística, com suas motivações e interesses, a fatores daquele preciso momento da história nacional.

Palavras-chave: Atividade artística; política; vida parlamentar; Constituição de 1891.

\section{Summary}

This article pursues two purposes: to restore the path realized by the painter Pedro Américo de Figueiredo e Melo to the First Constituent Republican Brazil and to analyze their participation in the discussions which gave legal basis to govern the country after the end of the monarchy. It does conjunction aspects of his personal and artistic life, with their motivations and interests, the factors that precise moment of national history. Keywords: Artistic activity; policy; parliamentary life; Constitution of 1891.



É preciso que todas as instituições artísticas ou científicas sejam protegidas, e é nessa conviç̧ão que hei de intervir com o meu esforço pessoal, quer apoiando o seu progresso, quer combatendo da tribuna toda e qualquer medida que possa embaraçá-las no seu desenvolvimento.

Pedro Américo de Figueiredo e Melo 
Este artigo se debruça sobre um domínio da vida do grande artista plástico e escritor do século XIX brasileiro, Pedro Américo de Figueiredo e Melo (Areia, Paraíba, 1843 - Florença, Itália, 1905), desconhecido da maior parte dos brasileiros, o de parlamentar em nossa Primeira Constituinte republicana.

Pedro Américo foi escolhido deputado federal pela Paraíba na eleição de 15 de setembro de 1890, para a sua primeira e única legislatura, juntamente com Epitácio Lindolfo da Silva Pessoa, Joaquim do Couto Cartaxo, João Batista de Sá Andrade, João da Silva Retumba, também eleitos deputados, e João Neiva, marechal Almeida Barreto e Firmino Gomes da Silveira, senadores (ALMEIDA, Tomo II, p. 176-177). Ele foi o segundo representante mais votado da Paraíba para integrar a Assembleia Constituinte de 1891, responsável por dar os esteios legais que permitiriam ao país funcionar dentro da nova ordem política instituída pela quartelada que depôs o imperador Pedro II, em 15 de novembro de 1889.

Se ex fructu cognoscitur arbor ${ }^{1}$, como timbra o provérbio medieval, arte e educação não poderiam deixar de ser as pedras angulares que dirigiram a participação parlamentar de Pedro Américo nos conturbados momentos em que o Brasil deixava o regime imperial e se encaminhava para a vida republicana. Com efeito, as ideias e projetos defendidos por Pedro Américo no nosso primeiro parlamento republicano espelham as convicções de um intelectual cuja vida fora nutrida, e vantajosamente, pela seiva que brota dos vínculos entre arte e conhecimento.

O talento extraordinário de Pedro Américo para as artes e seu desejo de saber muito cedo chamaram a atenção do imperador Pedro II, que inteligentemente o protegeu até onde lhe foi possível, garantindo-lhe meios de desenvolver as suas potencialidades artísticas e intelectuais. $\mathrm{O}$ apoio imperial permitiu-lhe, primeiro, concluir os estudos artísticos na Academia Imperial de Belas-Artes e, depois, rumar para a Europa a fim de aprimorar-se. O jovem artista brasileiro dirigiu-se a Paris a fim de completar, inicialmente, os seus estudos em artes plásticas ${ }^{2}$, e que logo terminaram, em razão de suas inclinações e ambições intelectuais, absorvendo outras áreas do saber. Em Paris, centro de irradiação artística e cultural dos mais importantes do século XIX, Pedro Américo assimilou e adaptou os conhecimentos de grandes mestres europeus das artes e das ciências. Isso ajudou a firmar ainda mais fundo em sua alma a convicção trazida de seus anos de convívio e estudos nos ambientes da Corte, em especial no da Academia Imperial de Belas-Artes: dos laços indestrutíveis entre arte e saber, entre sensibilidade expressiva e

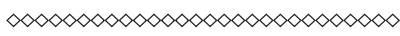

1 A árvore se conhece pelos frutos.

2 Pedro Américo partiu, em sua primeira viagem à Europa, para estudar na Academia de Belas-Artes francesa. Mas longe de permanecer nos limites do aprendizado artístico, o jovem areiense envolveu-se em diversas atividades formativas, das quais, a mais representativa, deste período, foi haver se matriculado no bacharelado em Ciências Naturais, na Sorbonne, de onde sairia diplomado. Não bastasse isso, empenhou-se nos fundamentos teórico-práticos do Neoclassicismo francês, com Léon Coignet, Hipollyte Flandrin e Horace Vernet, matriculou-se no curso de Física, de M. Ganot, e participou de outras atividades formadoras. 
conhecimento sistemático.

Para Pedro Américo - assim como para seu tempo - o Velho Continente era o grande celeiro cultural do mundo, que forneceria, especialmente a nós brasileiros, veios sólidos para o florescimento de uma nação civilizada nos trópicos. Não foi à toa, que Pedro Américo licenciou-se diversas vezes de suas atividades de professor da Academia Imperial de Belas-Artes e viajou para a Europa, sempre contando com o beneplácito do imperador Pedro II.

A série de viagens que empreendeu ao Velho Mundo representaram bem mais que a satisfação pessoal de um homem ilustrado em um meio cultural mais exigente; de fato, elas cumpriram um único objetivo cuidadosamente traçado: Pedro Américo ambicionava obter, na Europa, o reconhecimento de seu talento artístico e, também, de sua erudição. A arte do paraibano, e sua performance como homem de pensamento, iriam projetá-lo nos exigentes espaços da alta cultura europeia. Mas tal anseio era alimentado por um compromisso profundo, elevado, com a sua gente e com a sua terra. Sua obra e dotes pessoais dariam testemunhos de que o engenho brasileiro era capaz de produzir bem mais do que o amontoado de frutas, de produtos agrícolas e animais exóticos empalhados que ornavam os nossos stands nas concorridas exposições universais ${ }^{3}$ - e que estampavam o nosso atraso em relação às nações europeias. Por meio de suas realizações, pensava ele e alguns de sua geração, mostrar-se-ia a face de um país novo, que lutava para impor-se como nação civilizada.

Na maioria das vezes, Pedro Américo deixou o Brasil em direção à italiana Florença, e onde fixou residência em fase avançada da vida, depois de aposentado da Academia Imperial de Belas-Artes do Rio Janeiro. No "berço das artes", como ele próprio se referia à cidade de Giotto e Brunelleschi, executou painéis que o consagrariam, na Europa, como grande artista. De lá, Pedro Américo recebeu muitas manifestações de louvor ao seu talento, em número e em intensidade maiores que as colhidas no Brasil ${ }^{4}$. Alguns de seus quadros chegaram a ocupar por semanas as atenções da imprensa internacional. $\mathrm{O}$ sucesso conquistado em terras europeias se espalhou pelos jornais brasileiros, principalmente os da Corte, dando notícia da repercussão alcançada por suas composições. No

$\infty<\infty<\infty<\infty<\infty<\infty<\infty<\infty<\infty<\infty<\infty<\infty$

3 As exposições universais surgiram em meados do século XIX, como consequência do avanço do capitalismo industrial, e se constituíram na melhor expressão da força e anseios da mentalidade modernista. Elas têm origem no final do século XVIII, quando a França e a Inglaterra hospedaram as primeiras exposições. Antes as exposições apresentavam caráter nacional, e a partir de 1851 se transformaram em mostras internacionais, contando com a participação de europeus, americanos, africanos e orientais. As exposições universais abrigavam quatro categorias de produtos: manufaturas, maquinarias, matéria-prima e belas-artes. $\mathrm{O}$ Brasil começou a participar do certame de exposições universais em 1862, em Londres, e esteve presente nas de Paris (1867 e 1889), Viena (1873), Filadélfia (1876). As participações brasileiras estamparam caracteres exóticos, que provocaram curiosidade e frisson nos visitantes, como a de 1889, em que se expôs: "o estilo tropical, a monarquia selvagem, as riquezas naturais e a população com seus produtos bárbaros e mestiços" (SCHWARCS, 1998, p. 405).

4 Ver, a esse respeito, Pedro Américo, sua vida e sua obra (1993), escrita por J. M. Cardoso de Oliveira. 
Brasil, os grandes painéis que pintou foram objeto de polêmicas intermináveis travadas pelas páginas dos jornais do Rio de Janeiro ${ }^{5}$.

$\mathrm{O}$ areiense distinguiu-se nos ambientes cultos do Brasil ${ }^{6}$ e da Europa também por sua vasta erudição: falava com desenvoltura tanto sobre as belas-artes como sobre a filosofia, a história e a ciência moderna; poliglota, escrevia e conversava com fluência em francês, italiano, espanhol, e possivelmente em inglês; ficcionista, publicou quatro romances $^{7}$; ensaísta e homem de pensamento, deu a público discursos, teses, ensaios ${ }^{8}$, e um de seus trabalhos acadêmicos recebeu aplausos da imprensa belga; escreveu artigos e fez caricaturas para jornais do Rio de Janeiro; obteve o título de doutor em Ciências Naturais pela Universidade Livre da Bélgica, e lá também conquistou, com louvor, o posto de professor lente.

O menino pobre que saiu de sua modesta cidade natal aos 13 anos de idade em direção ao Rio de Janeiro para estudar, com a mala repleta de sonhos e de ambições de conhecimento e de arte, querendo se transformar num dos grandes do Império, vencera. Erguera-se em vida num triunfador invejadíssimo, e foi um dos intelectuais mais ferrenhamente perseguidos nestas terras tropicais, conforme assinala o sociólogo de Apipucos, Gilberto Freyre (1981, p. 97). Não foram poucas as campanhas anônimas e

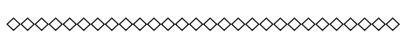

5 Alguns trechos dessas polêmicas constam da já citada obra do embaixador Cardoso de Oliveira. A mais famosa polêmica, e que tomou conta da imprensa da Corte, foi travada ao redor das telas monumentais $A$ Batalha do Avaí, de Pedro Américo, e A Batalha dos Guararapes, de Vítor Meireles de Lima. Expostas lado a lado, as telas conseguiram o prodígio de arrastar cerca de 30 mil pessoas para os corredores da Academia Imperial de Belas-Artes. Por semanas seguidas, os jornais publicaram artigos em que se discutia qual das duas obras era a mais bela, a mais bem elaborada, a que melhor atendia aos preceitos da pintura histórica etc. No livro A Batalha dos Guararapes, de João Zeferino Rangel de Sampaio, se encontra a mais completa ajuntada de artigos jornalísticos que alimentaram a mais célebre polêmica das artes plásticas nacionais. A obra de João Zeferino Rangel de Sampaio faz parte da Coleção Pedro Américo.

6 Assim se referira Gonzaga Duque, um dos melhores críticos de arte do Brasil do Segundo Reinado, a respeito de Pedro Américo, em sua obra Arte brasileira: pintura e escultura (1888):

Para se conhecer Américo, para se fazer uma ideia justa da sua organização moral puramente sentimentalista é preciso conversar com ele, sem prevenções, amigo para amigo, francamente, intimamente, entre as quatro paredes da sua oficina. Quando ele, por uma boa fé peculiar dos talentos superiores, esquece o mundo das negociações, dos preconceitos, das ambições hervadas, para deixar falar apenas o artista; quando põe de lado o dr. Pedro Américo de Figueiredo e Melo, para deixar falar o Américo, a simpatia que lhe dedicamos aumenta, origina-se em amizade, diante deste coração tão grande, dessa inteligência tão poderosa (p. 106).

7 Pedro Américo escreveu os seguintes romances: O holocausto (Florença, 1882), Amor d’esposo (Florença, 1886), O foragido (Paris, 1899) e Na cidade eterna (Paris, 1901). Os romances de Pedro Américo integram a Coleção Pedro Américo.

8 A Sorbonne publicou, de Pedro Américo, La réforme de L'École des Beaux-arts et la oposition, par un élève (Paris, 1863), ensaio em que historiou a reforma por que havia passado a instituição de ensino francesa. De sua fase de estudos na Universidade Livre da Bélgica, Pedro Américo publicou a sua tese doutoral, Memória sobre a conjugação da spyrogyra quinina e teoria da polaridade dos sexos (Bruxelas, 1869), Hipótese relativa à causa do fenômeno chamado luz zodiacal (Bruxelas, 1869), De l'enseignement libre des sciences naturelles (Bruxelas, 1869). A Universidade Livre da Bélgica publicou também a tese com que o artista brasileiro concorreu à cadeira de professor adjunto, La science et les systemes - questions d'histoire et de philosophie naturelle (Bruxelas, 1869). 
silenciosas movidas contra a obra de Pedro Américo, e contra as muitas pretensões que alimentara. Seus inimigos brandiram contra ele diversos artigos anônimos publicados nas páginas pagas dos jornais da Corte, porque incomodados com o seu estrondoso sucesso, e com a relativa atenção que Pedro II dispensava a seus pleitos ${ }^{9}$, especialmente os de afastamento de suas atividades de professor na Escola Imperial de Belas-Artes, para viajar à Europa.

Pedro Américo chegava à vida política, então, aos 47 anos de idade, escolhido entre outros pleiteantes por sua vasta folha de serviços prestada ao país, e pela enorme respeitabilidade que havia conquistado com muito trabalho, talento e pertinácia.

De sua caminhada até o Congresso Nacional, porém, quase nada se sabe. $\mathrm{O}$ documento mais significativo deste período de sua vida são os Discursos parlamentares: 1891 a 1892, publicados por Pedro Américo em 1892, e que recortam parte de sua atuação política, expondo momentos significativos de seus esforços para entregar à nascente nação republicana algumas diretrizes indispensáveis ao seu crescimento educativo e cultural. Seu mais autorizado biógrafo, o embaixador José Manoel Cardoso de Oliveira (18651962), deixou-nos apenas relatos parcos e inconsistentes de sua atividade política. O que, para nós, é muito sintomático, vindo de quem vem: genro do pintor, Cardoso de Oliveira era homem culto, e acompanhara de muito perto este período de sua vida, e certamente ouviu de Pedro Américo relatos sobre os eventos que marcaram sua vida política. Diplomata, Cardoso de Oliveira estava habituado às negociações políticas e aos jogos de bastidor em busca de acordos. Além disso, o biógrafo-genro foi promotor público, juiz municipal, romancista e poeta, e deixou obra considerável ${ }^{10}$.

"Onde há fumaça, há fogo", ensinam os desconfiados. E há motivos de sobra pra considerar que a economia de argumentos de José Manoel Cardoso de Oliveira fora pensada e calculada.

É verdade que Pedro Américo gravou seu nome para a posteridade por suas excepcionais qualidades de artista plástico, e não pelas investidas que fizera no terreno da política. E é natural que a maior parte do que se pesquisa e se escreve acerca do notável paraibano se incline sobre sua trajetória artística. Entendemos, também, que a atividade política de um artista consagrado, por menos "vitoriosos" que tenham sido seus esforços

$\infty<\infty<\infty<\infty<\infty<\infty<\infty<\infty<\infty<\infty<\infty<\infty$

9 Sobre esse assunto, ver nosso estudo introdutório à obra Pedro Américo - Biografia, de Luís Guimarães Júnior, primeiro número da Coleção Pedro Américo.

10 José Manoel Cardoso de Oliveira escreveu as seguintes obras: O orgulho (poemeto, 1885); Os précitos da senzala, (poemeto, 1885); Um milionário de glórias, notícia biográfica (Paris, 1899); Dos Alpes.... Flocos e Rimas, versos, Livraria (Paris, 1900); Le Gouffre - drama em 5 atos (Paris, 1901); O Sorvedouro, (Rio de Janeiro, 1902); Atos diplomáticos do Brasil (2 volumes, Rio de Janeiro, 1912); Dois metros e cinco, romance de costumes brasileiros (Rio de Janeiro, 1905, 1909 e 1936); Versos, (Rio de Janeiro, 1908); Poetas e prosadores portugueses (Lisboa, 1923); Discurso de recepção na Academia das Ciências de Lisboa (Lisboa, 1923); Catálogo descritivo, crítico e biográfico das obras do ilustre pintor Pedro Américo (Lisboa, 1924); A fé e a ciência. Nós, os brasileiros, conferência (Lisboa, 1926); O amor divino e a sua efígie na Terra, conferência, (Lisboa, 1926); Toques de claro-escuro (inédito). 
parlamentares - como ocorreu com Pedro Américo - constitui importantíssima fonte de informações sobre ele, como sobre o período histórico em que viveu.

Na tentativa de deixar um pouco menos turvos pontos importantes deste momento da trajetória de Pedro Américo, ensaiamos algumas respostas, ou melhor, possíveis respostas, armadas sobre fatos e indícios extraídos de documentos deste período de sua vida, entrecruzando-os com dados daquele preciso momento da história nacional. Os objetivos desta breve reflexão são os de pôr a descoberto o trajeto estabelecido por Pedro Américo para chegar ao posto de representante dos interesses populares, inserindo-o no quadro político-histórico de seu tempo, e avaliando a sua contribuição na Constituinte de 1891.

\section{Aspirações e estratégias para alçar-se deputado}

A admitir o que expôs seu mais autorizado biógrafo, haveremos de convir que foram, no mínimo, singulares os caminhos que levaram Pedro Américo ao Parlamento Nacional. Segundo ele, Pedro Américo chegou à candidatura a deputado do Congresso Constituinte por deliberação e empenho de alguns amigos de reconhecida influência (1993, p. 168). Com isso, o biógrafo dá a entender que a sua caminhada política veio da decisão de homens eminentes, que viam nele qualidades indispensáveis para ajudar a traçar as vias que o país percorreria na nova ordem política. Mas quem seriam esses amigos, o embaixador não informa.

Inusitada também foi a campanha eleitoral: ao invés de ir à Paraíba e percorrê-la atrás dos votos necessários à eleição, Pedro Américo retornou à Itália, onde havia deixado a família e trabalhos que exigiam sua atenção. O que Cardoso de Oliveira informa a este respeito não nos permite apreender muita coisa. O que teria levado o grande artista a deixar o Brasil neste delicado momento de sua vida? Por que um homem como Pedro Américo, acostumado a peitar grandes dificuldades, que enfrentara tantas batalhas e saíra vitorioso da maioria delas, preferia ficar a confortável distância do palco onde se desenrolaram as disputas sufragistas? De todo modo, é muito estranho que um candidato a cargo de tão alta relevância se afaste do país, justo no momento em que mais a sua presença se fazia necessária. Mas as curiosidades não param por aí.

Distante dos agitados momentos que marcaram as disputas eleitorais neste conturbado momento da história nacional, em que o país absorvia os solavancos da transição de um regime político para outro, é de se imaginar que Pedro Américo se poupava de desgastes que poderiam comprometer a sua eleição. É plausível supor que os longos anos que ficara longe da Paraíba iriam, certamente, lhe trazer alguns embaraços quando a campanha eleitoral se acirrasse. Segundo Elpídio de Almeida (1944), Pedro Américo retornou à Paraíba apenas duas vezes, depois de deixá-la, aos 13 anos de idade, para estudar no Rio de Janeiro. Entre 1864 e 65, ele visitou os pais, na cidade de Areia, e nunca mais voltou a vê-los. Em 1888, estivera na capital da Paraíba do Norte, mas imperiosos 
motivos levaram-no a suspender a viagem até a cidade natal. Em mãos dos adversários políticos, a ausência voluntária da terra natal, e a distância dos pais e irmãos, poderia se converter numa arma eficiente contra as pretensões eleitorais do artista. E ele não chegara a esta conclusão por meio de pura suposição: experimentara na própria pele os danos trazidos pela distância da terra natal, conforme ainda veremos.

Longe do corpo-a-corpo, e das inevitáveis pressões por que passam os postulantes a cargos eletivos, Pedro Américo lançou mão de cartas abertas, como instrumentos de campanha, que fez circular por toda a antiga província da Paraíba do Norte - como, aliás, era comum neste tempo. Apenas uma carta aberta de sua campanha eleitoral à Assembleia Constituinte se preservou, a que foi dirigida aos artistas brasileiros, datada de 15 de fevereiro de $1890^{11}$. Nesta carta, Pedro Américo apresentou sua candidatura aos artistas brasileiros, e os exortou a cerrar fileiras em torno de seu nome, distinguido artista e intelectual, que havia representado o Brasil com vigor e brilhantismo em ocasiões da mais alta relevância, inclusive diante de assembleias de príncipes e reis. Ele chamava a atenção para o esquecimento a que estavam submetidos os pintores, os arquitetos, os escultores, os decoradores no antigo regime, e para a urgente necessidade de restituir-lhes o lugar que por direito sempre foi seu no corpo da sociedade nacional.

$\infty<\times<\times<\times<\times<\times<\times<\times<\times<\times<\times<\infty$

11 Eis o teor desta carta aberta:

AOS SRS. ARTISTAS

Concidadãos e colegas!

Não conheço entre os antigos diretores da política da nossa pátria nenhum homem que compreenda a importância do artista brasileiro. Acostumado às lutas exclusivamente partidárias, e aos sofismas da demagogia imperial progenitora da descrença e do desânimo nacionais, quase todos se distinguiram pelo desdém votado aos representantes da atividade artística, e premiaram com o mais absoluto desprezo a maior parte daqueles de quem, muitas vezes, dependeram os seus triunfos. Era do trabalho, entretanto, ou dos seus representantes que dependiam, se fossem acatados e considerados, a prosperidade pátria e as melhores parcelas da riqueza pública.

Exercer o espírito e os braços em mister útil e honrado, transformar a argila, os metais, as matérias-primas e utilizáveis em outras tantas fontes de opulência e prosperidade, era quase uma recomendação demeritória aos olhos dos próceres da nação, demasiado distraídos pelas satisfações do poder para descerem às considerações práticas da existência coletiva do operário, e demasiado orgulhosos para apertarem com prazer a mão calejada no glorioso exército do trabalho.

No parlamento brasileiro - assembleia promíscua de homens doutos e de crassas nulidades - jamais figurou um artista, e nem uma vez foi este apelido citado nas posturas e mais regulamentos municipais da famigerada corte! Os nossos legisladores como que receavam deturpar a candidez dos códigos e estatutos de uma terra de servos e escravos escrevendo, mesmo entre as denominações de tantos centenares de especuladores de toda a espécie o nome que enche de esplendor a fronte de tantas nações ilustres da Europa, como se depois de cobrir de glória a Itália, a França, a Espanha, a Bélgica e a Alemanha, não fosse esse nome antes um brasão e uma auréola para o povo brasileiro.

A preocupação pessoal afastava da mente do político o sentimento dos deveres transcendentes, e de contínuo o aconselhava a decretar antecipadamente a decadência efetiva e real de todos aqueles que nutriam veleidades de independência de profissão ou de caráter, porque esses podiam estorvar-lhes a marcha triunfante por entre as ruínas da pátria.

Só um dever sobrevivia a todos os outros, e era o de não desagradarem aos partidos dos quais dependiam sua posição e fortuna. De modo que, verdadeiros párias da sociedade, os pintores, os arquitetos, os escultores, os decoradores, todos aqueles, enfim, que compunham a numerosa classe dos trabalhadores, 
No parlamento brasileiro - assembleia promíscua de homens doutos a de crassas nulidades - jamais figurou um artista, e nem uma vez foi este apelido citado nas posturas e mais regulamentos municipais da famigerada corte! [...]

É contra esse olvido dos imprescindíveis deveres do político, contra essa espécie de ostracismo votado a todo operário, a todo artífice, a todo homem útil e singelo, que se deve elevar o espírito nacional em nome dos princípios da democracia americana, cujos triunfos confortam o nosso coração de patriota, e cujas deslumbrantes irradiações iluminam os horizontes da terra brasileira, até agora entenebrecidos pelo mais irremediável desânimo.

Conforme assinalamos, não faltou economia a Cardoso de Oliveira ao referir-se às decisões relativas à vida política de Pedro Américo, que dependeu muito mais de "alguns amigos de reconhecida influência" do que da vontade e da determinação do grande artista brasileiro. De fato, o embaixador contara - e muito mal - apenas uma pequena parte da história.

Nas condições em que corre uma campanha eleitoral, é de se imaginar que Pedro Américo tivera apoios importantes, especialmente em seu estado natal. Era preciso contar com agentes que intercedessem a seu favor junto do eleitorado; que divulgassem as suas cartas abertas e fizessem o eleitor ver que o nome do conterrâneo, que tantas vezes honrou a sua terra e a sua gente, era o melhor para representar os interesses do estado da

quaisquer que fossem as manifestações do seu engenho e da sua atividade produtiva, formavam como uma chusma de mentecaptos, sem importância nem significação na ordem das coisas, porque não constituíam um órgão especial e forte no implacável mecanismo das derrotas e triunfos eleitorais.

É contra esse olvido dos imprescindíveis deveres do político, contra essa espécie de ostracismo votado a todo operário, a todo artífice, a todo homem útil e singelo, que se deve elevar o espírito nacional em nome dos princípios da democracia americana, cujos triunfos confortam o nosso coração de patriota, e cujas deslumbrantes irradiações iluminam os horizontes da terra brasileira, até agora entenebrecidos pelo mais irremediável desânimo.

Haverá quem, sob a sagrada égide da República vitoriosa, possa nutrir no seu seio um sentimento discorde com a dignidade humana? Ainda haverá um artista que não tenha consciência do seu valor, da sua independência, da sua missão como membro de uma sociedade altamente predestinada? Quais aspirações, quais desejos e anelos poderão hoje apoderar-se do ânimo dos brasileiros, senão os que devem convir aos filhos deste século de progresso, de luz à de liberdade?

E também haverá entre os futuros legisladores da pátria regenerada um único que desconheça que sem as belas-artes, sem as artes mecânicas, sem os transformadores da matéria utilizável e os produtores dos cabedais nacionais nenhum povo pode conhecer os benefícios da civilização e da opulência? Na Alemanha, na França, nos Estados Unidos, na Suíça e na Itália os promotores de quase todos os progressos de caráter civilizador têm sido, em geral, os grandes artistas, aos quais a nação reconhecida decretou cadeiras de honra nas assembleias legislativas, ou estátuas e lápides comemorativas nas praças públicas.

Verdi* é um simples músico, Morelli* um simples pintor, Monteverdi* um escultor, e não obstante se terem sempre abstido de figurar nas lutas dos partidos, possuem suas cadeiras no senado italiano, ao lado dos príncipes de sangue e das maiores ilustrações da ciência e da política.

A vós, artífices de tantos gêneros, modestos e gloriosos representantes da soberania popular simbolizada na soberania do engenho e da profissão, cumpre agora cogitar do futuro e decidir qual sorte preferis na próxima reorganização do país: se o sistemático olvido de que foram sempre objeto a vossa classe e as vossas profissões, se o vosso ingresso na órbita dos elementos da próxima grandeza da República, na qual vos deveis

44 Cartema-No3-Ano 2 - Dezembro 2014 
Paraíba e do Brasil no Parlamento Nacional. Isso, se tivéssemos pela frente uma eleição normal. O que não ocorreu.

Além de outras coisas, Cardoso de Oliveira se esquecera de dizer que ocupar uma cadeira no Legislativo Nacional era um antigo projeto de Pedro Américo, que começou a tomar corpo por volta dos vinte anos de idade, quando se achava em Paris, instruindo-se e aprimorando-se nas melhores escolas da velha cidade. Durante o tempo em que o jovem pintor brasileiro permaneceu na Cidade das Luzes (1859-1864), manteve corres-

recomendar por Vós mesmos ao respeito do legislador brasileiro, para que sagre para sempre a arte nos solenes areópagos da Pátria regenerada.

A vós incumbe enviardes um artífice ao seio do Parlamento em que se tem de decretar a forma definitiva da Instituição Democrática Brasileira; porque importa desde já demonstrardes aos adeptos da política há pouco decaída, que ainda não perdestes o sentimento dos vossos deveres patrióticos e o direito de sufragar um dos vossos.

Quantos melhoramentos não há que promover nessa formosa parte da América do Sul, para suavizar a sorte do operário, do artista, e desenvolver nas gerações novas as vocações especiais! Quantas instituições a criar para modificar a ingratidão das circunstâncias que algemam o artista, e jungem às vezes o seu espírito ao carro de uma miséria tão injusta quanto é nele nobre o ardor do trabalho e profundas as decepções granjeadas nas lutas da existência! Eu não sei qual situação exista mais credora da atenção do legislador, e dos cuidados de um governo previdente e sábio.

Fui, no Rio de Janeiro, presidente da Liga Operária, quando aquela associação contava em seu seio mais de cinco mil adeptos, e conheço pelos malogrados esforços da diretoria no intuito de melhorar a sorte do artista e do operário, antipatia com que semelhante instituição, toda de fraternidade e socorro mútuo, era tratada pelos antigos estadistas, os quais negavam-lhe tudo quanto podia garantir-lhe a existência, e até - por conceituarem-na de índole liberal e republicana - a aprovação dos respectivos estatutos, em que entretanto se evidenciavam a ordem, as intenções pacíficas e o fim moralizador que tínhamos em vista. Desanimado, abandonei o posto de honra, depois de ver que, adversa à felicidade dos cidadãos, a corruptora política conseguira introduzir a discórdia entre os membros da associação, e pretendia reduzir esta a uma simples máquina de guerra ao serviço dos partidos dominantes.

A proclamação do regimen democrático no Brasil deve banir do nosso solo até os últimos vestígios desse espírito dissolutor e imoral, a que deve o brasileiro o desânimo que o imobilizava, e esse Estado o seu atraso, a sua pobreza e a sua absoluta decadência.

A convite do Governo francês assisti às festas e tomei parte nos congressos celebrados por ocasião da última Exposição Universal de Paris - grandioso concurso de todas as maravilhas do engenho humano e de todos os produtos da civilização -, e entre tantos representantes das associações operárias de todas as grandes nações do mundo, não tive o prazer de ver um único do meu país; e eu próprio, que ali representei gratuitamente a minha pátria no Congresso internacional para a proteção das obras de arte e dos monumentos históricos, ao qual presidi por aclamação dos seus ilustres membros, depois de um trabalho indefesso durante mais de um mês e de grandes sacrifícios pecuniários para corresponder dignamente às reiteradas gentilezas e atenções de que me faziam objeto, não tive do governo imperial um simples agradecimento, e nem uma resposta, sequer, às comunicações que lhe fiz e ao relatório que lhe mandei acerca dos meus estudos e das decisões do referido Congresso. Tal era o desprezo que no deposto regímen premiava o esforço do artista brasileiro e acolhia os trabalhos dignos de atenção!

Acostumado às lutas do pensamento, aos combates com a adversidade, à independência da palavra $\mathrm{e}$ das ações, forte pela segurança de poder viver honestamente em qualquer parte do mundo sem jamais ser pesado aos cofres do meu país, nem carecer embair a opinião pública para obter a glória que só esperei do meu trabalho, eu tenho, pois, razão para esperar de Vós a alta distinção de vos representar no seio da próxima Assembleia Constituinte, como tantas vezes - sem proteção oficial nem encargo pecuniário -, entre assembleias de príncipes e reis representei o nome brasileiro, glorificando pela arte os fatos mais notáveis da nossa história. 
pondência com o naturalista francês Louis-Jacques Brunet ${ }^{12}$, residente na capital pernambucana.

A estreita relação de Pedro Américo com Brunet iniciou-se em 1854, quando o naturalista, contratado pelo governo da Província da Paraíba do Norte, incorporou à sua equipe de desbravadores dos rincões nordestinos um prodigioso menino de onze anos, que registrou em desenhos a flora e a fauna da região. Pedro Américo acompanhou a expedição chefiada por Brunet por cerca de vinte meses, atravessando os então selváticos sertões da Paraíba do Norte, Ceará, Rio Grande do Norte e Piauí, aprendendo com o naturalista noções de ciências naturais e o idioma francês.

Em correspondência endereçada ao naturalista, enviada de Paris, com a data de 7 de novembro de $1863^{13}$, o jovem artista manifesta seu interesse em ingressar na política nacional:

Tenho tido a lembrança de lançar-me na política de meu país, ao chegar lá, parecendo-me este o único e o mais incontestável meio de servir ao progresso de nosso desenvolvimento intelectual. No Brasil não há elementos para que sob a influência dos ideais de uma Escola, o estudo das belas-artes se possa espalhar, como se vulgarizaram os estudos das letras. Não há localidade, por menor que seja, não há um só recanto habitado no Brasil, que não tenha uma aula de latim, onde bem ou mal ensina-se a conhecer literatura romana. Entretanto, em uma tão rica nação, em um país que reclama a tantos títulos o nome de civilizado, não há uma só instituição favorável às belas-artes e por consequência a uma das fontes mais abundantes de prosperidade pública: à indústria comercial.

[...] Sem falar dos bem-feitos de sua cultura sobre a civilização, apresentaria, se me envolvesse na política, os resultados práticos do ensino das belas-artes entre nós; o que se compreende mais facilmente no Brasil, onde o reinado dos caminhos do ferro e do desenvolvimento material deve suceder evidentemente à apatia em que temos vivido, apesar de termos tantos homens devotados ao bem público e ao interesse geral. É pois convencido que poderia obter alguns frutos mais saborosos do que os que produziram os esforços encerrados em um atelier, que me tenho lembrado da carreira política para servir ao país e às belas-artes, porquanto as palavras pronunciadas no seio do parlamento são as que edificam e organizam a sociedade.

Fraternalmente vos saúda o

vosso confrade e amigo

Pedro Américo de Figueiredo

Florença, 15 de fevereiro de 1890

12 Nas poucas cartas trocadas entre Pedro Américo e Brunet que se preservaram, há indicações de que mantinham correspondência regular. Algumas delas encontram-se no Instituto Histórico e Geográfico da Paraíba, em João Pessoa.

13 O leitor encontrará a íntegra desta correspondência na obra Cartas de Pedro Américo, um dos volumes da Coleção Pedro Américo. 
Outras cartas de Pedro Américo a Brunet exporiam a mesma pretensão, como é o caso da que traz a data de 24 de novembro de $1863^{14}$, da qual extraímos os trechos a seguir:

[...] Falei-lhe ultimamente de política, e como verá, deixo aparecer ça et là, na carta que dirijo ao nosso amigo Catoulé, algumas ideias a respeito. Tenho um desejo imenso de fundar alguma coisa no Brasil, de não perder lá o que tenho ganho aqui, de completar essa civilização tão imperfeita, reclamando para as Belas-Artes e mais ramos de conhecimentos que ilustram a nação, um lugar menos estreito na instrução pública.

Mas como poderei eu dar peso às minhas ideias e palavras, se ficar estranho à política, que tudo dirige?

Se me perguntassem a quem incumbe fazer prosperar as artes, eu tão depressa responderia aos artistas, como dizem e pensam muitos, como c'est au légis à opérer ce prodige ${ }^{15}$, segundo diria Aristóteles!

Entretanto, como na [falta] das dignas os fundadores sempre são mártires, eu só ousarei expor ideias novas se me vir ao abrigo de altos protetores.

Hei de parecer-lhe talvez um utopista; mas, meu amigo, quando se tem 23 anos [sic] e um coração cheio de patriotismo, vendo-se prestes a definhar e morrer em uma sociedade jovem, que não aceita facilmente senão princípios d'um interesse positivo, será possível pensar de outra maneira, ou calar quando se pensa assim?

Outro detalhe da maior importância passou longe dos olhos de seus biógrafos: a ambição de Pedro Américo de ocupar uma cadeira no Parlamento Nacional era antiga. Nove anos antes do pleito que o levou ao Congresso Nacional, Pedro Américo lançara-se candidato à Assembleia Imperial. Em carta aberta, datada de 11 de julho de $1881^{16}$,

$\infty<\infty<\infty<\infty<\infty<\infty<\infty<\infty<\infty<\infty<\infty<\infty<$

14 O leitor encontrará a íntegra desta e de outras correspondências do artista brasileiro na obra Cartas de Pedro Américo, que integra esta Coleção.

15 É ao legislador que cabe operar este prodígio.

16 Esta carta aberta está no Museu Regional de Areia, Paraíba. Reproduzimo-la, a seguir, integralmente:

AOS SRS. ELEITORES

DO CÍRCULO DA CIDADE DE AREIA.

Filho estremecido da Paraíba do Norte, d'onde poderosas circunstâncias me têm afastado, educado nas lutas do pensamento, que enobrecem a alma e sublimam o caráter, e conhecido de quantos no mundo têm noção dos últimos progressos das belas-artes e das ciências filosóficas na nossa América, eu não interromperia por certo o fio das minhas ocupações estéticas e das minhas pesquisas científicas, a obra a um tempo civilizadora e deleitável que empreendi, não acudiria à voz que me convoca à arena dos combates políticos, se em mim o sentimento patriótico não sobrelevasse as considerações pessoais. Convencido, porém, que é dever de todo o cidadão esquecer a si mesmo por amor de seus conterrâneos, aceito a candidatura que espontaneamente me oferecem os meus afetos, na esperança de que a minha presença entre os ilustrados atletas do progresso, longe de perturbar a paz dos que laboram na edificação da Pátria, seja para todos um penhor de concórdia, e como um novo elo para a cadeia que nos prende à comunhão de uma só ideia. 
o artista paraibano se dirigiu aos eleitores de Areia, anunciando a sua candidatura e pedindo-lhes apoio. Dela, destacamos dois trechos:

Filho estremecido da Paraíba do Norte, d’onde poderosas circunstâncias me têm afastado, educado nas lutas do pensamento, que enobrecem a alma e sublimam o caráter, e conhecido de quantos no mundo têm noção dos últimos progressos das belas-artes e das ciências filosóficas na nossa América, eu não interromperia por certo o fio das minhas ocupações estéticas e das minhas pesquisas científicas, a obra a um tempo civilizadora e deleitável que empreendi, não acudiria à voz que me convoca à arena dos combates políticos, se em mim o sentimento patriótico não sobrelevasse as considerações pessoais. Convencido, porém, que é dever de todo o cidadão esquecer a si mesmo por amor de seus conterrâneos, aceito a candidatura que espontaneamente me oferecem os meus afetos, na esperança de que a minha presença entre os ilustrados atletas do progresso, longe de perturbar a paz dos que laboram na edificação da Pátria, seja para todos um penhor de concórdia, e como um novo elo para a cadeia que nos prende à comunhão de uma só ideia.

Ainda que ausente da minha terra natal, não tenho deixado de acompanhar os diferentes aspectos por que tem passado a sua história com as diversas situações políticas, interessando-me particularmente por tudo quanto se refere às instituições de utilidade geral; e, força é dizê-lo, nem dos esforços dos mais ilustrados representantes do Parlamento nacional, nem do influxo do universal progresso, nem da sensível expansão do seu comércio, das variações da sua nascente indústria, da vitalidade moral dos seus filhos e, finalmente, das louváveis tentativas com que a política tem buscado melhorar o estado geral da Província, tenho visto derivarem os resultados a que tem direito de aspirar essa formosa parte do Império sobre a qual espalhou a Natureza tantos dos seus inexauríveis tesouros.

E entretanto, quantas forças se não teriam aproveitado, quantos progressos se não teriam realizado na agricultura, no comércio, na instrução pública, no método de transformar as matérias-primas e multiplicar os recursos intelectuais e materiais do produtor se, em vez de se consumirem em lutas estéreis, tivessem sempre patenteado em patrióticas os dotes de sua invejável organização tantos belos engenhos que aí têm feito carreira pela política!

Fora erro, porém, atribuir-se-lhes os males originados em circunstâncias que transcendem a órbita da Província, não raro acusada de morosidade na falsíssima hipótese do quase geral progresso das suas congêneres, muitas das quais permanecem imóveis, ao passo que em países estrangeiros a magnitude dos acontecimentos científicos, comerciais, artísticos, industriais e políticos vão transformando a existência e imprimindo nova feição à face das coisas.

Os recentes trabalhos da estrada de ferro destinada a multiplicar a atividade da Província tornam credores da gratidão pública os promotores e propugnadores desse incomensurável benefício; ao mesmo tempo que a ausência de outros melhoramentos gerais, como sejam vias férreas econômicas em todas as direções, a exemplo das da Lombardia e do Piemonte; de ativa navegação fluvial e costeagem, como em França, na Inglaterra, na Itália e nos Estados Unidos, de viação fácil e racional, como em toda a Europa central; de estabelecimentos metalúrgicos, como na Suécia, na Rússia e na Espanha; ou de melhoramentos econômicos, como institutos e bancos agrícolas à semelhança dos de França, da Bélgica, da Prússia; de caixas rurais instituídas sob o plano das da Inglaterra, da Baviera e da Hungria, ou melhoramentos intelectuais, como escolas agrárias elementares, onde os agricultores aprendessem a multiplicar a uberdade do solo e a analisar os produtos do seu trabalho; fazendas-modelo, nas quais, segundo o que acontece na Austrália, na Sicília e na Estíria, pudessem os lavradores instruir-se pelo exemplo e aumentarem pela imitação o valor de suas terras; de alguma arte que, segundo o que acontece na Itália medieval e acontece na França contemporânea, inspirasse as vocações especiais para a carreira do belo; de estabelecimentos de instrução teórica para as classes abastadas e prática para o proletariado; e, finalmente, de trabalhos hidráulicos destinados a minorar as ter-

48 Cartema- $N^{\circ} 3-$ Ano 2 - Dezembro 2014 
Ainda que ausente da minha terra natal, não tenho deixado de acompanhar os diferentes aspectos por que tem passado a sua história com as diversas situações políticas, interessando-me particularmente por tudo quanto se refere às instituições de utilidade geral; e, força é dizê-lo, nem dos esforços dos mais ilustrados representantes do Parlamento Nacional, nem do influxo do universal progresso, nem da sensível expansão do seu comércio, das variações da sua nascente indústria, da vitalidade moral dos seus filhos e, finalmente, das louváveis tentativas com que a política tem buscado melhorar o estado geral da Província, tenho visto derivarem os resultados a que tem direito de aspirar essa formosa parte do Império sobre a qual espalhou a Natureza tantos dos seus inexauríveis tesouros.

Nada se sabe acerca desta passagem da vida de Pedro Américo: se desistiu da candidatura, se não recebeu votação suficiente etc. O certo mesmo é que ele não se elegeu.

Vê-se nesta carta aberta que Pedro Américo fizera sua campanha ao Parlamento do Império distante da Paraíba. Nos dois trechos anteriores, o artista se escusa por estar longe da terra natal, afirmando que poderosas circunstâncias o teriam impedido de ter com os conterrâneos. Mesmo a distância, diz não desconhecer o que se passa na Paraíba do Norte, e tampouco está alheio aos desdobramentos políticos que aí ocorreram. Se "o que anda na boca anda também no coração", como lembra o ditado popular, percebe-se que a distância de sua terra natal o incomodava. E Pedro Américo tinha motivos de sobra para se preocupar com a prolongada ausência. No Rio de Janeiro, enfrentara, muitas

ríveis consequências das secas - flagelo que se repete segundo leis meteorológicas, climatéricas, geológicas e topográficas de fácil interpretação -; a ausência, digo, desses e de muitos outros atributos da civilização, condição de toda a prosperidade em uma sociedade moderna, aí nos está mostrando a arduidade da tarefa que incumbem ao político os altos destinos dessa formosa Província, cuja extensão e recursos naturais de todo o gênero, bem que medíocres comparados aos de outras províncias do Império, são, todavia, superiores aos de muitas nações notáveis da Europa, como a Bélgica, a Holanda, a Dinamarca, a Suíça, a Grécia e a Romênia, as quais em tempo relativamente breve colonizaram-se, progrediram e civilizaram-se pelo constante esforço dos filhos, e não por circunstâncias casuais ou pelo atuar de decretos superiores à vontade humana, como muitos o creem e outros adrede o propalam para encobrir a própria incapacidade e a ineficácia das teorias de que se imbuem.

Os meus contínuos estudos das teorias naturais, filosóficas e sociais nos países mais adiantados da Europa, a minha prolongada convivência com os seus mais ilustres cultores da ciência e da arte, a constante observação dos fenômenos econômicos e políticos progenitores do progresso neste grande foco de luz cujos raios iluminam todas as nações do mundo; o conhecimento da legislação de tantos povos diversos pela raça, pela índole e pelos costumes; e, além disso, a experiência das coisas do meu país, e em particular da Paraíba - que já percorri em toda a sua extensão - incutem-me no espírito a convicção de que invejáveis propensões ingênitas dos meus Comprovincianos, a sua inteligência no cultivo de todos os ramos de conhecimentos, a sua atividade na vida política, a facilidade com que abraça as ideias nobres e generosas, a sua sensibilidade, o seu heroísmo manifestado nas batalhas núncias das vitórias do Império; a sua admirável resignação durante as calamidades públicas; e, com esses elementos de grandeza cívica, a uberdade quase geral do solo paraibano, a variedade dos climas e das produções naturais de tão bem dotada terra, e até a sua situação geográfica intermediária aos dois extremos do Brasil, não são fatos que se possam eliminar dos cálculos que evidenciam os altos destinos dessa formosíssima Província. 
vezes, problemas para deixar o país em direção à Europa. Seus opositores, e em especial os anônimos, iam para os jornais acusá-lo de viver mais na Europa do que no Brasil, à custa dos cofres imperiais.

É bem possível que esse tenha sido o calcanhar-de-aquiles de sua campanha à Assembleia Imperial, por onde os adversários demoliram as suas pretensões parlamentares. E, por tal razão, era também necessário não insistir, agora pretendente a ocupar uma cadeira na primeira Assembleia Constituinte republicana, no afastamento de seu estado natal em seus veículos de propaganda. Tanto é assim, que na carta aberta aos artistas, a de 1890, o candidato Pedro Américo não faz qualquer referência a isso. Tampouco seria conveniente retornar à Paraíba justo no momento da campanha eleitoral, o que poderia ser interpretado como atitude de interesse exclusivamente político - e talvez os danos às suas pretensões, com a sua presença, fossem bem maiores.

E é também razoável se considerar que, a se repetirem as mesmas circunstâncias da frustrada candidatura de 1881, as chances de Pedro Américo ocupar uma cadeira na Assembleia Nacional Constituinte de 1891 eram muito remotas. Se as condições de sua

E quantas vezes, atravessando no vapor os campos agricultados e floridos deste velho e cansado continente, ou as entranhas das suas serras perfuradas, transpondo pelas pontes pênseis os leitos dos seus rios navegáveis e o seio dos vales ajardinados; avistando as suas costas artesoadas e a luz dos seus faróis elétricos; visitando os seus arsenais gigantescos, suas grandiosas alfândegas, suas vastíssimas fábricas, suas galerias de arte, suas coleções científicas, suas doutas academias, seus estabelecimentos astronômicos, mecânicos, industriais; ou interrogando os seus monumentos históricos, admirando os primores do seu engenho, contemplando as maravilhas da sua inteligência patenteada nos descobrimentos da química, da fisiologia e em geral das ciências positivas e biológicas; conversando de viva voz com pessoas distantes de mim centenares de quilômetros; vendo irrigadas e férteis planícies outrora adustas e áridas, achanadas as montanhas, cortados os continentes, e como suprimidas as distâncias que separam os diversos povos; quantas vezes, enfim, cogitando em tantos prodígios da atividade humana, e procurando descobrir as leis da aspiração geral das sociedades à plenitude do direito e da liberdade, não voou o meu pensamento até a terra do meu berço, como a esperança em busca do país da promissão destinado a receber ele encerra mais grandioso nos seus inefáveis arrebatamentos do ideal!

A legislação, porém, desse país em que eu tinha fixada a minha mente como em astro de alento era um obstáculo invencível para que a mim, simples operário do verdadeiro e do belo, fosse permitido colaborar diretamente com o estadista e o soldado no aperfeiçoamento e exornação da Pátria; e semelhante ao nauta que aguarda o vento favorável para lançar-se aos oceanos onde talvez o traguem as tempestades, esperei nos decretos da Província como quem conhece a irrefreável progressão do direito na consciência dos povos predestinados. Obrigado assim a encerrar na esfera aparentemente plácida da cogitação e da arte as aspirações do meu patriotismo, procurei desenvolver os sentimentos estéticos da Nação, tornando ao mesmo tempo conhecidos desde o Prata até o Neva as glórias brasileiras e o nome Paraibano; e quando, durante a última seca que flagelou os nossos sertões, chegou aos meus ouvidos a voz de tantas vítimas da assombrosa calamidade, não fui surdo aos gemidos dos meus infelizes Comprovincianos: antes, assinando-lhes a melhor parte do produto da exibição dos meus trabalhos, pungiu-me o pesar de não poder dispor de inesgotáveis cabedais para os socorrer.

E, pois, no descontinuar a carreira e, que nunca deixei de manifestar o meu amor à Pátria, alenta-me a esperança de encontrar nos ilustrados Eleitores desse Círculo o apoio para que me seja permitido pagar ao meu país natal o tributo de gratidão que lhe devo, fazendo ecoar no Parlamento Brasileiro a voz dos meus Comprovincianos, e concorrendo para tornar cada vez mais incontestáveis no seio da Representação Nacional os títulos que os tornam dignos da geral consideração e do respeito do legislador.

Roma, 16 de julho de 1881.

Dr. Pedro Américo de Figueiredo. 
eleição eram difíceis, é preciso então admitir que poderosas forças políticas se uniram em torno de seu nome, a ponto dele ter sido sufragado (ou algo parecido com isso) em excelente posição. Afinal, a situação da Paraíba era a basicamente a mesma de nove anos antes. Pedro Américo era conhecido em seu Estado natal, não temos dúvida, mas apenas por estreitas faixas da população, as camadas urbanas mais informadas. A maior parte da população paraibana neste período estava mergulhada na ignorância, assim como o resto do país. Os índices educacionais de 1872 mostram que o Brasil apresentava graves índices de analfabetismo:

Em 1872, entre os escravos, o índice de analfabetos atingia 99\% e entre a população livre aproximadamente $80 \%$, subindo para mais $86 \%$ quando consideramos só as mulheres. Mesmo descontando-se o fato de que os percentuais se à população total, sem excluir crianças nos primeiros anos de vida, eles são bastante elevados. Apurou-se que somente $16,85 \%$ da população entre seis e quinze anos freqüentavam escolas. Havia apenas 12 mil alunos matriculados em colégios secundários. Entretanto, calcula-se que chegava a 8 mil o número de pessoas com educação superior no país. Um abismo separava, pois, a elite letrada da grande massa de analfabetos e gente com educação rudimentar (FAUSTO, 1995, p. 237).

Desde 1881, uma reforma eleitoral havia associado a renda mínima e a exigência de o eleitor ser alfabetizado, o que resultou numa drástica diminuição do número de eleitores (PRYORE e VENÂNCIO, 2001, p. 266).

Uma coisa, porém, havia mudado, e abruptamente: o regime político. O marechal Deodoro da Fonseca, líder do movimento militar que pôs abaixo a Monarquia, tornou-se chefe do governo provisório, e passou imediatamente a nomear os governadores dos estados. A mentalidade que então passava a coordenar a vida do país não expressava os interesses de uma classe social, a exemplo da que defendia o modelo de República liberal. Entre os militares não havia consenso acerca da concepção de governo para o país. Ao lado de Deodoro da Fonseca, posicionaram-se os "tarimbeiros"17, e quase todos tinham lutado na Guerra do Paraguai. "Eles haviam ajudado a derrubar a Monarquia para salvar a honra do Exército e não possuíam uma visão elaborada de República, a não ser a ideia de que o Exército deveria ter um papel maior do que o desempenhado no Império" (FAUSTO, 1995, p. 246). Ao redor de Floriano Peixoto reuniram-se os jovens oficiais egressos da Escola Militar, formados sob a influência do positivismo, e que se viam na condição de soldados-cidadãos, cuja missão era imprimir sentido e ordem à vida política do Brasil. As diferenças de concepção, porém, cederam espaço à ideia de que o país necessitava de um Poder Executivo forte, ou passar por um período mais ou menos longo de ditadura.

$\infty<\infty<<<<<<<<<<<<<<<<<<<<<<$

17 Referência à tarimba, cama desconfortável em que dormem os soldados. 
Do Rio de Janeiro, o governo provisório investiu no cargo de governador da Paraíba o juiz de direito de Catolé do Rocha, Venâncio Neiva. E, como era praxe no começo da República, o governo provisório nomeara também os auxiliares diretos de Venâncio Neiva: Epitácio Pessoa, para secretário-geral, e João Coelho Gonçalves Lisboa, para chefe de polícia (ALMEIDA, 1997, p. 176). Foi no governo de Venâncio Neiva que transcorreram as eleições para escolher os representantes paraibanos ao Congresso Constituinte.

Assim como ocorreu em outras partes do país, as eleições de 15 de setembro de 1890 para a Assembleia Constituinte, na Paraíba, são consideradas fraudulentas (ALENCAR et al., 1979, p. 193), porque manipuladas pelos militares vinculados ao marechal Deodoro da Fonseca. No governo de Deodoro da Fonseca algumas dezenas de oficiais foram eleitos para o Congresso Constituinte. E em muitos estados da recém-criada federação, a população viu espantada candidatos completamente desconhecidos saírem eleitos das urnas. Se fraudes eleitorais já eram comuns na Paraíba, como no resto do país, durante a Monarquia, o que dizer de um período de nossa história em que um regime de força assentava representantes militares e civis em diversos postos da administração e da vida política, e todos subordinados, claro, ao comando da capital federal?

Diante de tal quadro político e institucional, a inconsistência das informações deixadas por Cardoso de Oliveira parecem querer dizer que a escolha de Pedro Américo adveio de um "acordo de gabinete", firmado com altos agentes da recém-instituída República. Tratou-se, então e ao que tudo indica, de uma eleição de "favas contadas". E o calculado silêncio de Cardoso de Oliveira queria mesmo era deixar no limbo acontecimentos que culminaram num processo eleitoral viciado, manipulado pelos altos escalões militares, a centenas de quilômetros da Paraíba, em estreita associação com forças políticas locais.

Outros motivos concorrem para dar consistência a essa suspeita. Vejamos.

É necessário não perder de vista que Pedro Américo foi um homem de enorme projeção em seu tempo, e que soube criar vínculos e relações de amizade com diversas personalidades do Império, entre as quais as militares. Pedro Américo se distinguira, dentro e fora do país, como "pintor de batalhas", eternizando em grandes telas feitos militares recentes, quase todos vinculados à campanha brasileira na Guerra do Paraguai, como a Passagem do Chaco (1871), Batalha de Campo Grande (1871), O ataque da Ilha do Carvalho (1872), Combate do Itapiru (1874), Passo da Pátria (1874), A Batalha do Avaí (1877).

Pedro Américo, assim como Vítor Meireles, eram os pintores brasileiros que mais atendiam às exigências de criação e solidificação da imagem pública que o país se esforçava por estabelecer. É bem sabido que o Estado imperial brasileiro tomara as belas-artes como esteios indispensáveis de celebração de uma nova ordem, segundo os interesses de uma nação nova que precisava de símbolos que "alardeassem" a sua grandeza. O imaginário da nova nação tropical, assim, alimentou-se de obras artísticas que estamparam eventos e personagens capazes de marcar a nossa soberania, como os que ressaltaram nossa individualidade étnica, através do indianismo, e feitos históricos que expuseram nossa determinação guerreira, como os conflitos com os holandeses e os paraguaios. 
Pedro Américo decidiu-se pelos recentes embates com os paraguaios, que teriam boa acolhida nos altos escalões do Estado imperial, responsáveis pela contratação de seus serviços de artista plástico, ou pela compra de suas composições. Nem é preciso muito esforço para se concluir que Pedro Américo mantinha boas relações com altas patentes militares, bem como conquistara respeito e alguma estima junto aos oficiais. Afinal, tratara muitas vezes, pessoalmente ou por carta, com diferentes oficiais para obter informações fiéis sobre o que se passara nos campos de batalha. Tantas vezes desenhou e redesenhou croquis de seus quadros, atendendo a essa ou àquela solicitação para mudar a feição, a posição, o detalhe de fardamento de um combatente. Pintara oficiais brasileiros em momentos em que a refrega contra os paraguaios atingia o clímax, reservando-lhes lugar de destaque nas composições. Entregara ao país a imagem de um Exército forte, organizado, destemido. Deixara multidões extasiadas, dentro e fora do país, com a monumentalidade da Batalha do Avaí, com as façanhas de intrépidos homens de farda que entregaram a vida nas mãos da sorte por amor ao país e ao Imperador. A ideia, portanto, de Pedro Américo ocupar uma das cadeiras de deputado federal na Constituinte era, certamente, bem-vinda para um governo provisório formado por militares.

Outro trecho da biografia escrita por Cardoso de Oliveira é também sugestivo. Diz o embaixador: "Achava-se Pedro Américo na Capital Federal, quando o pranteado Benjamin Constant, ministro do Governo Provisório, convidou-o para com ele colaborar na reforma da Academia das Belas-Artes” (1993, p. 167). Segundo o embaixador, a ideia predominante entre os promotores da reforma era pela extinção da Academia de Belas-Artes, para se criar com o material existente o museu de pintura e escultura, restando todos os professores demitidos. Inclusive, um projeto nesta direção havia sido apresentado já impresso, e aguardava decisão. Após indicado seu nome para o Congresso Constituinte, e a bordo do Nord America, em direção à Europa, Pedro Américo aproveitou para elaborar uma minuta de projeto de reforma do ensino artístico no país ${ }^{18}$ - bem diferente, aliás, da proposta que andava circulando pelos gabinetes governamentais, e que optava pela simples extinção da Escola de Belas-Artes, e portanto por sepultar o ensino de arte no Brasil.

Mas a questão que nos interessa é outra. Benjamin Constant era ministro do Governo Provisório, e umas das lideranças do Exército, ao lado de Deodoro da Fonseca. Dificilmente saberemos o que aconteceu neste encontro entre Benjamin Constant e Pedro Américo; restou-nos, apenas, a menção de que o ministro militar solicitou o empenho do artista brasileiro na reforma da Academia de Belas-Artes. É curioso que após a conversa com um dos militares mais respeitados da República tenha surgido a indicação do nome de Pedro Américo para deputado do Congresso Constituinte pelo seu estado natal.

$\infty<\infty<\infty<\infty<\infty<\infty<\infty<\infty<\infty<\infty<\infty<\infty<$

18 Este esboço de projeto encontra-se nos anexos de Os discursos parlamentares: 1891 a 1892, um dos volumes da Coleção Pedro Américo. 
Acrescente-se a isso o fato de ser bem conhecida a simpatia que Pedro Américo nutria pelo regime republicano, e algumas de suas correspondências são muito esclarecedoras a esse respeito. Em uma de suas cartas a João Coelho Gonçalves Lisboa ${ }^{19}$, Pedro Américo informava que recebeu, em Florença, telegrama de um ministro do governo Deodoro da Fonseca, pedindo-lhe para escrever artigos à imprensa europeia, a fim de esclarecer a opinião pública do Velho Mundo acerca do momento político vivido no Brasil. Eis um trecho desta correspondência:

A representação da grande e esperançosa República Brasileira tem sido cruelmente insultada pela imprensa assalariada deste ninho de reis e príncipes anacrônicos (rasgado) nem sempre as calúnias assacadas contra os gloriosos fundadores do atual regime democrático têm produzido no público o efeito desejado pelos imperialistas, graças em primeiro lugar ao explorador dos próprios fatos e em segundo ao esforço com que essas calúnias têm sido desenvolvidas pelos amigos da grande e gloriosa instituição política que regenerou nossa pátria. O Ministro do (rasgado) parece ter adivinhado meu pensamento (rasgado) me distinguir com um longo telegrama, convidando-me a esclarecer à imprensa francesa, italiana, alemã, etc., a respeito dos acontecimentos do Brasil: em comunicados aos principais órgãos da Europa, eu já havia procurado restabelecer a verdade, e quase sempre tão vitoriosamente que conto fazê-los mudar de linguagem e até elogiarem com a maior franqueza a nossa República e os nossos compatriotas beneméritos.

Por aí se percebe que antes mesmo de ter sido solicitado oficialmente a emprestar sua pena e seu prestígio pessoal à causa republicana de seu país, Pedro Américo se adiantara, tomando a iniciativa de escrever aos jornais europeus, defendendo os interesses do novo regime. O seu empenho como porta-voz dos interesses republicanos brotara de suas convicções políticas, como também é certo que isso haveria de favorecê-lo, no momento apropriado, em suas pretensões diante do governo brasileiro.

Se, da parte do Governo Provisório, conforme imaginamos, não haveria resistências para que seu nome integrasse o rol de parlamentares da Primeira Constituinte republicana, restava ter em seu estado natal o apoio indispensável para que se elegesse. E esse apoio veio de um conhecido republicano, João Coelho Gonçalves Lisboa, nomeado, por Deodoro da Fonseca, chefe de polícia da Paraíba. Na correspondência antes citada, fica claro que a eleição de Pedro Américo contou com a intervenção de Gonçalves Lisboa. Nela, o pintor e intelectual paraibano solicitou-lhe apoio à sua candidatura à Assembleia



19 O leitor encontrará o teor completo desta correspondência em Cartas de Pedro Américo, que integra a Coleção Pedro Américo. 
Constituinte. O pedido tinha, sim, motivações de natureza política, mas a ele se acrescentaram, também, os fortes laços de amizade entre Gonçalves Lisboa e João Antônio de Figueiredo e Melo, irmão de Pedro Américo. Os vínculos fraternais entre a autoridade estadual e o irmão do pintor permitiram, mesmo a distância, estabelecer as condições locais favoráveis à sua eleição. Veja-se o trecho a seguir da citada correspondência:

Já tive a honra de comunicar a V. Excia. uns impressos que dirigi aos meus conterrâneos, e nos quais eu lhes pedia acolherem com benevolência a minha candidatura a uma cadeira na próxima Constituinte. Tomei a liberdade de invocar igualmente apoio de Quem tão grandes provas de confiança e amizade se tem dignado de dar a meu irmão João Antônio de Figueiredo; e, fazendo-o, eu estava certo de não desmerecer do seu ilustrado concurso. O fim desta não é mais, como o da minha primeira carta, meramente político, porém mais do que isto, o de lhe agradecer tamanha bondade, assegurando-lhe que o caráter e a honestidade do meu irmão são bem dignas das distinções de que acaba de ser objeto.

Podemos dar por certo que Pedro Américo não tenha se dirigido à sua cidade natal, Areia, para formalizar a sua candidatura. E isso porque, em outra correspondência, enviada de Florença e dirigida a Gonçalves Lisboa, datada de 14 de dezembro de $1889^{20}$, o pintor e intelectual paraibano afirma o seguinte:

[...] Na luta que se vai empenhar deverá haver de nossa parte grande receio das adesões calculadas de homens gastos, aos quais deve esse Estado o seu relativo atraso e sua absoluta pobreza, e que não deixaram de introduzir no novo aspecto das coisas o espírito reacionário de que necessariamente hão de estar possuídos perante o glorioso quadro que os acontecimentos tão rapidamente acabam de esboçar no firmamento da Pátria Brasileira.

Ignoro a época das eleições, mas procurarei informar-me para partir a tempo. Se estas se fazem como pelo passado, será bom apresentar-me no $3^{\circ}$. distrito, isto é, pela cidade de Areia, etc. O meu programa é do Governo.

Conto com o seu valioso apoio e com estima me assino de V. Excia. patrício e amo. criado.

Segundo relatos de Cardoso de Oliveira (1993, p. 168), Pedro Américo recebeu, em Florença, a notícia de que havia sido escolhido deputado federal pela Paraíba.

$\infty<\infty<\infty<\infty<\infty<\infty<\infty<\infty<\infty<\infty<\infty<\infty<\infty$

20 O leitor poderá ver o teor integral desta correspondência em Cartas de Pedro Américo. 


\section{Os projetos do artista-parlamentar}

Qualquer que tenha sido o caminho percorrido por Pedro Américo para chegar ao mandato político, naqueles conturbados momentos iniciais de nossa vida republicana, haverá certamente de ceder espaço à qualidade de seu trabalho parlamentar. O conjunto de projetos trazidos à apreciação da Câmara Federal mostram que Pedro Américo estava decidido a apresentar alternativas institucionais que permitissem ultrapassar os graves índices de atraso educativo e cultural da nação, especialmente os relativos ao ensino universitário e à vida artística e intelectual.

Pedro Américo elaborou os seguintes projetos: A criação de três universidades; a fundação de uma galeria nacional de belas-artes independente da Escola de Belas-Artes (o que só viria, de fato, a ocorrer em 1937, com a criação do Museu Nacional de Artes Plásticas); a criação de um teatro nacional; a abolição das loterias e de outros jogos desumanos (como os espetáculos de touro); a repressão dos costumes dissolutos; a lei sobre propriedade artística e literária e os direitos autorais.

Os projetos que viu aprovados, porém, foram os que trataram de questões políticas urgentes, como o que concedeu auxílio financeiro ao Estado da Paraíba; e "dentre as emendas que apresentou ou apoiou com a sua assinatura, a que reduziu o período presidencial a quatro anos, e a que concedeu pensão vitalícia a d. Pedro de Alcântara" (OLIVEIRA, 1993, p. 171).

Embora as propostas apresentadas por Pedro Américo fossem da maior relevância para o desenvolvimento educacional e cultural do país, não conseguiram sensibilizar os parlamentares, muito mais ocupados com o instável cenário político da Nação. E os congressistas tinham razões de sobra para estar preocupados. O País vivia um clima político em que as forças republicanas divergiam acerca dos rumos a serem tomados na elaboração da Carta Magna. Enquanto o marechal Deodoro da Fonseca, os positivistas e parte do Exército queriam um regime centralizado, os grupos dominantes dos principais Estados almejavam assegurar o princípio federalista e representativo, que iria garantir a sua participação no Governo. Três meses após o Congresso Constituinte ter dado início aos trabalhos, foi promulgada a primeira Constituição republicana, em 24 de fevereiro de 1891, baseada na Carta dos Estados Unidos. Para as oligarquias estaduais, a promulgação da Constituição foi uma vitória, porque se garantia a autonomia dos Estados. A Constituição, elaborada e aprovada às pressas, dá bem uma noção da situação política que o Brasil enfrentou neste período.

E um dia após a Promulgação da primeira Constituição republicana, o Congresso Nacional se veria agitado com a eleição indireta do presidente e do vice-presidente do Brasil. De um lado, as oligarquias sustentaram o nome do presidente do Congresso Constituinte, Prudente de Morais, e do marechal Floriano Peixoto como seu vice. Mas, os boatos de que os militares preparavam uma intervenção para impor o nome de Deodoro da Fonseca, deram-lhe a vitória, por um placar apertado: 32 votos a mais que Prudente de Morais (cf. ALENCAR, CARPI, RIBEIRO, 1979, p. 194). E Floriano Peixoto elegera-se vice-presidente. 
O período em que o marechal Deodoro da Fonseca ocupou a cadeira presidencial foi marcado por uma sucessão de crises, que se refletiam no Congresso Nacional. Deodoro afastou todos os presidentes de Estado que apoiaram a candidatura de Prudente de Morais. Em fins de outubro, a Câmara Federal conseguiu aprovar projeto que regulamentava os atos do Legislativo e do Executivo. Em seguida, os parlamentares impuseram mais uma derrota ao cabeça do Executivo, negando-lhe um pedido para a emissão de 600.000 contos. Foi, também, a "gota d'água", porque, ato contínuo, o marechal Deodoro da Fonseca dissolveu o Congresso Nacional e encarcerou os principais líderes oposicionistas (cf. ALENCAR, CARPI e RIBEIRO, 1979, p. 194).

A reação não tardou. Com o apoio do vice-presidente da República, Floriano Peixoto e militares, os trabalhadores da Central do Brasil entraram em greve, protestando contra o ato de fechamento do Congresso. Diante de tantos abalos, Deodoro da Fonseca renunciou a 23 de novembro de 1891, e Floriano Peixoto assumiu a presidência da República. Mesmo tendo chegado à presidência do país armado de muito poder - apoiado pelo Exército e pelas oligarquias descontentes com o governo de Deodoro da Fonseca Floriano Peixoto enfrentaria situações muito tensas durante o seu mandato.

\section{Um artista na disputa política}

Nem precisamos ir muito longe para nos certificar que, num clima politicamente tão agitado como o que retratamos aqui, não poderiam prosperar propostas como as desenhadas por Pedro Américo. E também não é de se espantar que a "falta de ouvidos" do Congresso Nacional aos seus projetos tenha lhe causado profunda decepção, porque chegara à Câmara Federal certo de poder contribuir com sua larga experiência e erudição para o aprimoramento do país.

A passagem de Pedro Américo pelas regiões do poder público no Brasil foi, aliás, um curto incidente da sua carreira, que não lhe deixou saudades, nem influiu de modo apreciável na marcha dos negócios do país (p. 170).

Republicano, culto e humanista, aquela havia sido a oportunidade de sua vida de pôr em andamento, enfim, as aspirações que durante tanto tempo alimentara: de intervir, positivamente, nos destinos de seu povo, criando instituições e mecanismos que ajudassem a formar cidadãos conscientes de seu papel e de seus deveres diante de um país empobrecido que precisava crescer. E Pedro Américo entendia que não seria possível o país pôr-se em marcha de crescimento, igualar-se às grandes nações de seu tempo, se a maior parte da população brasileira continuasse submetida às graves condições de pobreza e ignorância. Era urgente, pois, criar e fortalecer instituições capazes de fazer com que alcançássemos, de modo mais rápido e consistente, a posição de nação culta e desenvolvida. 
Desde a mocidade, Pedro Américo estava convencido de que era dever do Estado garantir os meios para que trilhássemos os caminhos da prosperidade, somente possíveis se o poder público estendesse os benefícios da educação e da cultura aos seus cidadãos, a todos, indistintamente. Caso contrário, o país continuaria a amargar a descrença em suas potencialidades, e permaneceríamos desprezando (como ainda hoje desprezamos) a maior parte do que recebe o selo de nacional em proveito do que vem das nações mais desenvolvidas. Nas Considerações filosóficas sobre as belas-artes entre os antigos ${ }^{21}$ - obra de juventude e a primeira, aliás, a refletir sobre o papel das belas-artes no desenvolvimento e fortalecimento da nação brasileira - Pedro Américo chamava a atenção, em 1864, para a urgente necessidade de se criar meios de garantir a instrução do brasileiro:

Cultivemos, pois, as belas-artes, que deixaremos algum dia de parecer inferiores às raças europeias, quando considerarmos as nossas produções, quer puramente artísticas quer industriais. E, para cultivar com êxito, não esqueçamos da instrução do povo, primeira função de um estado, sem a qual não se podem elevar as massas ao sentimento do belo.

Ficam, aí, os testemunhos da atividade parlamentar de um grande brasileiro, que em meio às refregas políticas que marcaram os primeiros anos de nossa República, procurou, o quanto pode e suas energias permitiram, criar meios para que chegássemos à condição de nação civilizada.

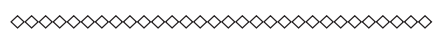

21 Esta obra parece ter sido iniciada em 1864, quando Pedro Américo se preparava para retornar ao Brasil, após período de estudos de cinco anos na capital dos franceses. Ele foi publicado pelo Correio Mercantil, do Rio de Janeiro, em 20 edições, entre 30 de setembro e 28 de dezembro de 1864. Neste mesmo ano, Pedro Américo presenteou o Imperador Pedro II com o manuscrito desta obra e com a tela A carioca, como provas de sua gratidão e de seu crescimento intelectual e artístico, que tanto contaram com a ajuda do soberano. Este ensaio integra a Coleção Pedro Américo. 


\section{Referências bibliográficas}

ALENCAR, Francisco, CARPI, Lúcia e RIBEIRO, Marcus Venício. História da sociedade brasileira. Rio de Janeiro: Ao Livro Técnico, 1979.

ALMEIDA, Elpídio. Pedro Américo e seu Torrão Natal. In: ALMEIDA, Horácio (org.). Pedro Américo - Centenário de seu nascimento. João Pessoa: A União, 1944.

ALMEIDA, Horácio de. História da Paraíba. 3 ed. João Pessoa: Editora Universitária; Conselho Estadual de Cultura, 1997. (Tomos I e II).

ARRUDA, José Octávio de. História da Paraíba: lutas e resistência. 5 ed. João Pessoa: Editora Universitária, 1997.

DEL PRYORE, Mary e VENÂNCIO, Renato. O livro de ouro da história do Brasil. Rio de Janeiro: Ediouro, 2001.

DUQUE-ESTRADA, Luís Gonzaga. Arte brasileira: pintura e escultura. Rio de Janeiro: H. Lombaerts \& Cia., 1888.

. Impressões de um amador: textos esparsos de crítica (1882-1909). Belo Horizonte: Editora UFMG; Rio de Janeiro: Fundação Casa de Rui Barbosa, 2001. (Inéditos \& Esparsos).

Mocidade morta. 4a ed. Rio de Janeiro: Fundação Casa de Rui Barbosa, 1995.

FAUSTO, Boris. História do Brasil. 2 ed. São Paulo: Edusp/IDE, 1995.

GALVÃO, Alfredo. Manuel de Araújo Porto Alegre: sua influência na Academia Imperial das Belas-Artes e no meio artístico do Rio de Janeiro. Rio de Janeiro: IPHAN, 1959. (Separata da Revista do Patrimônio Histórico e Artístico Nacional, v. 14).

GUimARÃES JÚNIOR, Luiz. Pedro Américo. Rio de Janeiro: Henrique Brown e João de Almeida Editores, 1871. (Galeria Brasileira, 2).

GUINSBURG, J. (org.). O romantismo. 2a ed. São Paulo: Perspectiva, 1985. (Stylus, 3).

HOLANDA, Sérgio Buarque de (dir.). História geral da civilização brasileira. $6^{\mathrm{a}}$ ed. Rio de Janeiro: Bertrand do Brasil, 1987. (O Brasil monárquico, tomo II, $3^{\circ}$ v., $n^{\circ}$ 5).

MARTINS, Lincoln. Pedro Américo, pintor universal. João Pessoa: Governo do Estado da Paraíba; Brasília: Fundação Banco do Brasil, 1994.

MARTINS, Wilson. História da inteligência brasileira. São Paulo: Cultrix; Editora da Universidade de São Paulo, 1977-78. (vol. III, IV).

MELLO JÚNIOR, Donato. Pedro Américo de Figueiredo e Melo: 1843-1905. Algumas singularidades de sua vida e de sua obra. Rio de Janeiro: Edições Pinakotheke, 1983.

MELO, Pedro Américo de Figueiredo e. Alguns discursos. Florença: Imprensa de l'Arte della Stampa, 1888. (2a parte).

Amor d’esposo - narrativa histórica. Florença: Imprensa de l’Arte della Stampa, 1886.

Discursos parlamentares: 1891 a 1892. Rio de Janeiro: Imprensa Nacional, 1892.

La réforme de l'École de Beaux-Arts et la opposition (Par un élève). Paris:

A. Morel et Cie., 1863.

O pintor-parlamentar Pedro Américo em meio às turbulências da Constituinte de 1891 
OLIVEIRA, Cecília Helena de Salles e MATTOS, Claudia Valladão (orgs.) O brado do Ipiranga. São Paulo: Editora da Universidade de São Paulo; Museu Paulista da Universidade de São Paulo, 1999. (Acervo, 2).

OLIVEIRA, J. M. Cardoso de. Pedro Américo: sua vida e suas obras. $2^{\text {a }}$ ed. fac-sim., Brasília: Centro Gráfico do Senado Federal, 1993.

SCHWARCS, Lilia Moritz. As barbas do imperador: D. Pedro II, um monarca nos trópicos. $3^{\text {a }}$ reimp. São Paulo: Companhia das Letras, 1998.

. O espetáculo das raças - Cientistas, instituições e questão racial no Brasil: 1870 - 1930. São Paulo: Companhia das Letras, 1993.

SCHWARZ, Roberto. Ao vencedor as batatas - forma literária e processo social nos inícios do romance brasileiro. $3^{a}$ ed. São Paulo: Livraria Duas Cidades, 1988. (v. I) SILVA, Demócrito de Castro e. Pedro Américo: poeta das cores e pintor de batalhas. João Pessoa: Secretaria da Educação e Cultura/Governo do Estado da Paraíba, 1982.

SILVA, Silvano Alves Bezerra da. Pedro Américo: Gênio da Raça Brasileira. In: MELO, Pedro Américo de Figueiredo e. A ciência e os sistemas - questões de história e de filosofia natural. João Pessoa: Editora Universitária, 1999.

SILVA, Silvano Alves Bezerra da. Pedro Américo e o processo de construção nacional das belas-artes. In: MELO, Pedro Américo de Figueiredo e. Considerações filosóficas sobre as belas-artes entre os antigos. João Pessoa: Editora Universitária, 2006. 